Canadian University Music Review

Revue de musique des universités canadiennes

\title{
Notes on Harp of David
}

John Beckwith

Volume 11, numéro 2, 1991

URI : https://id.erudit.org/iderudit/1014110ar

DOI : https://doi.org/10.7202/1014110ar

Aller au sommaire du numéro

Éditeur(s)

Canadian University Music Society / Société de musique des universités

canadiennes

ISSN

0710-0353 (imprimé)

2291-2436 (numérique)

Découvrir la revue

Citer cet article

Beckwith, J. (1991). Notes on Harp of David. Canadian University Music Review / Revue de musique des universités canadiennes, 11(2), 122-135.

https://doi.org/10.7202/1014110ar

(c) Canadian University Music Society / Société de musique des universités canadiennes, 1991
Ce document est protégé par la loi sur le droit d'auteur. L'utilisation des services d’Érudit (y compris la reproduction) est assujettie à sa politique d'utilisation que vous pouvez consulter en ligne.

https://apropos.erudit.org/fr/usagers/politique-dutilisation/ 


\title{
NOTES ON HARP OF DAVID
}

\author{
John Beckwith
}

These notes do not constitute a critical analysis; that would be a task for someone other than myself. Rather, they amount to a sort of log of the work's evolution, a post-compositional exercise which in fact I have not attempted with any of my other pieces. The reaction of some students, colleagues, and performers, to whom I have shown them, persuaded me they may be worth sharing.

This cycle of six psalm-settings for a-cappella chorus ${ }^{1}$ had a number of causes. First, in my head for a long time was a vague notion of setting some psalm-texts, from the old Book of Common Prayer version, as a tribute to my mother, who often used to quote favourite phrases ("my cup runneth over," "who going into the vale of misery useth it for a well," "the mountains skipped like lambs"), and with whom I sang them in a church choir many years ago. Second, in 1982 I heard the Elmer Iseler Singers perform on two occasions Monteverdi's Lagrime d'amante, and was struck by the intense effect of close to half an hour of acappella choral music, and by the unexpectedly wide range of colors and textures. Third, I had, over a period of twenty years or more, delved into early psalmody and hymnody, especially in their Canadian aspects, had taught this material to my students, and in 1984-5 was actively engaged in editing an anthology of tunes from early Canadian collections. ${ }^{2}$ Further, I had composed two choral works based on traditional hymn tunes - Sharon Fragments (1966) and Three Motets on Swan's 'China' (1981) $)^{3}$ - and found continuing interest in the beauty of this literature and in its potential for variational and other kinds of treatment.

The fourth cause was the one which really ignited the enterprise. Late in 1984, a good friend from college days, Rev. R.F. Shepherd, was elected Anglican

${ }^{1}$ Beckwith, J.: Harp of David. London, Ontario: Iroquois Press (a division of Jaymar Music Ltd.). 1992. Centrediscs CMC-CD 3790, 1990; Vancouver Chamber Choir, Jon Washburn conducting.

2 The Canadian Musical Heritage, vol. 5, Hymn tunes, ed. J. Beckwith. Ottawa: Canadian Musical Heritage Society, 1986.

${ }^{3}$ Both are published by Waterloo. Sharon Fragments is recorded on Angel/Seraphim S 60085, and Three Motets on Swan's 'China' on Melbourne SMLP 4041 and RCI ACM 26. 
Bishop of British Columbia, and asked me to compose a piece to be sung at his installation. I responded with a setting of Psalm 65, which now forms the first movement of Harp of David; it was performed by the choir of Christ Church Cathedral in Victoria (where I used to sing as a boy) under the direction of Michael Gormley. Ronald Shepherd had approved the text, one of several possibilities we considered in consultation: blessing is called on "the man whom thou choosest," the spirit of a happy, laughing earth seemed appropriate, and the rain images accorded especially well with the West Coast locale.

The following spring I set Psalm 80, now the fourth movement. Shortly afterwards I drafted a plan for the cycle, chose further texts, and composed successively Psalms 122 and 87 (together; now the sixth movement), Psalm 148 (now No.5), Psalm 1 (No.3), and Psalm 130 (No.2). The first two movements (1 and 4) drew respectively on a Scottish psalm tune ("London New," 1635) and a tune from the earliest hymnal of Wesleyan Methodism ("Foundery," 1742). For the other four movements, I borrowed tunes from other periods and from traditions with comparable pertinence in Canadian terms - for No.2, "Aus tiefer Not,"Lutheran, 1524; for No.3, "Psaume 1,"Calvinist, 1542; for No.5, "Beautiful River,” U.S., 1864; and for No.6, “Remembrance," New Brunswick, 1816.

The texts for all six movements are those of the Book of Common Prayer of 1562. But in each movement except No.5 I added portions of corresponding verseparaphrases, juxtaposing these with the prose in various ways; and again these verses are all taken from different historical sources (some older bibles printed them as a supplement): that in No. 1 from the first North American collection, the Bay Psalm Book, 1640; those in Nos. 2 and 3 from the same sources as their melodies, the first Lutheran songbooks and the Geneva Psalter respectively; that in No.4 from Isaac Watts' The Psalms of David imitated in the language of the New Testament, 1722; and that in No. 6 from the Methodist poet John Newton.

The $B C P$ texts are each set in full - with only two modifications. In No. 5 , the last few lines are slightly re-arranged. In No. 6, I freely interleaved the related texts of two different Psalms (122 and 87), omitting some lines; and in order to clarify Psalm 87 I added a separate translation from the New English Bible for a couple of puzzling verses.

The magnificent poetry of the Book of Psalms has been a source for many composers. In working on these settings I thought often of the emphasis on psalm-singing in virtually all historical ages of the Judeo-Christian tradition (in some, psalms were the only texts permitted to be sung by the people), and of the recurrences of psalms in Hebrew and Latin chanting; in the versified vernaculars of 16th-century France, Germany, Holland, England, found in the earliest 
protestant chorale and hymn-tune sources; and in the folklike, sometimes crudely-produced, collections of 18th-century North America, to which the music of the great gospel-revival movements is indebted for many traits of harmony, melody, and rhythmic motion. It was to this long, unbroken usage by human groups for their musical expressions of feeling that I felt attracted in developing my ideas - rather than to any particular religious or liturgical interpretation (I am not a churchgoer).

The cycle's subject matter covers a necessarily limited range but nevertheless touches on several of the psalmist's recurrent themes. (I avoided the more bloodthirsty and vengeful psalms, however.) No.1 is a song of praise. Its opening reference to Sion/Jerusalem (the "holy city") will be expanded in No. 6. Praise here is sustained with recollections of God's might amid celebrations in a happy productive land. No. 2 is a famous lament, an agonized cry of suffering, and a prayer for mercy. I may have linked it in my mind with the first biblical text I ever set to music, the long cry of Jonah from what he refers to as "the belly of Hell." No. 3 is the sermon-like text with which the Psalter begins, and treats a subject to which the author frequently returns, notably in the longest of the 150 (Psalm 119) - namely, the law of reason which dictates a choice of good over evil ways of living. In No. 4, the range of the psalmist's feelings is unusual, his rhetoric difficult: the tone at times is that of the sufferer who asks, "why $m e$ ?" The literary form, with its recurrent refrain, strikes me as spacious and elegant. The text for No. 5 typifies the exuberant and joyous praises of the last few psalms. Its symmetrical numbering of first heavenly and then earthly celebrants (first angels and stars, and then cattle, worms, people...) suggests a natural division into two stanzas. In No. 6, two different texts about the special communal qualities of an idealized Jerusalem and its equally idealized Hill of Sion are woven together for mutual reinforcement of some of their individual lines. In certain of the lines, poignancy arises as one is reminded of the actual city and hill in recent history.

The music applies a variety of techniques and effects. Though performable individually, the movements are arranged in a deliberate order for contrast of subject and mood and also for a certain tonal logic (the centres of the six movements are D, E, F, F-sharp, E-flat, C). I often employ the melodic transformations of serialism, without abandoning the diatonic character of the given melodies or of the new lines I have derived from them. A precedent for this is found in a group of works by Igor Stravinsky from the 1950s, notably his Cantata and Three Songs from William Shakespeare.

In the technical comments on individual movements, the abbreviations $\mathrm{O}, \mathrm{I}, \mathrm{R}$, and RI refer to the standard terms Original, Inversion, Retrograde, and Retro- 
grade Inversion - the four angles from which one may view a set of pitches without altering its intervallic unity -, while numerals denote the transpositions of the set to the eleven available starting-points in standard Western tuning (thus, zero, or 0 , means the original position, 1 the position a semitone higher, 5 the position five semitones higher). Therefore, if $\mathrm{O}^{0}$ begins on the pitch $\mathrm{E}$, then $\mathrm{I}^{10}$ indicates the real inversion of the same set beginning ten semitones higher, on $\mathrm{D}$; and if $\mathrm{O}^{0}$ ends on $\mathrm{B}$-flat, then $\mathrm{R}^{7}$ indicates the same set in retrograde order beginning seven semitones higher, on $\mathrm{F}$.

Even to some professionals, I know, all this will appear too arbitrary, brainy, "mathematical." But in my view it is no more so than, for example, the rudimentary triadic and scalic relationships most musically-aware people understand in the concept "A major." The composer is afforded a number of fresh advantages by such possibilities, of which three may be cited. The first is the freedom from fixed rhythmic patterns whereby the given set will be recognized only if certain of its member pitches occur on strong beats. The second is the identity of the set whichever direction its constituent intervals may take (the close intervals of the start of No. 4 and the wide intervals in the passage starting at the first "più mosso" are perceived as variations of each other). A third advantage is the major/minor inflections which arise from use of real (as opposed to tonally-adjusted) forms of inversion and retrograde-inversion. If, as in No. 1, the given melody (the set, as it may be regarded) has a "major mode" character, the exact reproduction of its intervals by inversion will produce a "minor mode" character. Though fairly obvious, this property of the lines can be exploited for expressions akin to those of common-practice tonality, for example the juxtaposing of major and minor phrases by a composer such as Schubert.

No.l (Psalm LXV). The given fully syllabic Common-Metre melody is treated as a 28-note set (the pitches are enumerated 0-27). One transposition only is used. I found after having completed a good deal of the composition that I had made an error in quoting "London New" (I evidently quoted it from memory): in the third phrase, the cadential notes (19-21) should be B-B-A, whereas I recalled from an inner harmonic voice the notes $A-G$-sharp-A. Having drawn a good deal of emphasis to the odd pitch here, the G-sharp, I was reluctant to go back and "correct" the piece, and rationalized that the version I adopted is in fact a cadence pattern found in several other Scottish and English psalm melodies of the same period as "London New" (See Ex. 1).

Pp. 3-8. The chorus sings the first three verses to $O$ and $R$ (the point of retrogradation occurs on the first syllable of 'un-to' in verse 2). A group of eight solo voices hums freely various arpeggiations of the D major triad (such 


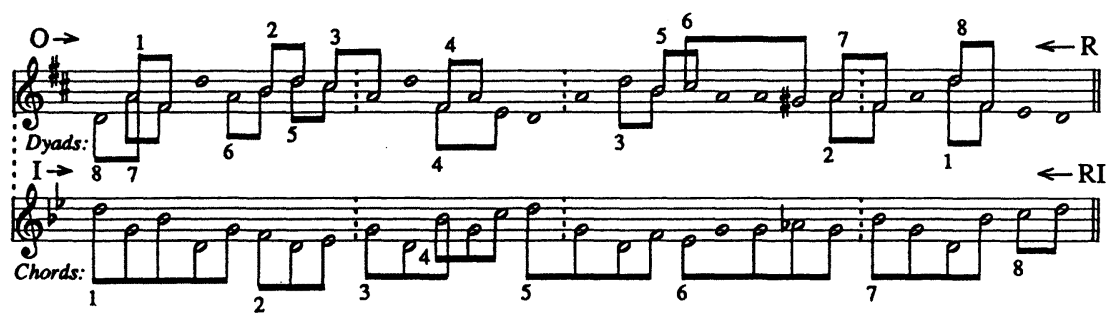

Example 1

formations make up a large portion of the original melody - notes $0-4,8-11,13-$ 15, and 21-25). A similar texture, of soloists accompanying the choir instead of the more conventional reverse situation, is used in the second of my Three Motets on Swan's 'China'.

Slower, pp. 8-10. Chords formed from $\mathrm{I}^{0}$ are used as a background to the unison declamation of verses 4 and 5 . The formation of these eight chords is shown in line 2 of Ex. 1; they proceed in the order 1 to 8 and then in retrograde $\left(\mathrm{RI}^{0}\right), 8$ to 1 . The vocables of the accompanying voices are derived from the phonemes of the text - a treatment which I have followed in several of my other works for choir, and which occurs here again in No. 3.

Slightly faster,pp. 10-12. Bimodal canons: the women's voices sing dyads made from $\mathrm{O}^{0}$, while the men's voices complement these with dyads made from $\mathrm{I}^{7}$. At "who stillest," the forms become $\mathrm{I}^{7}$ for the women and $\mathrm{O}^{0}$ for the men; at "they also," and again at "thou that makest," the lines again exchange. The major chord formations of $\mathrm{O}$ become minor in the I form, so that these simultaneities have a major/minor coloring.

Slower, pp. 12-14. Paralleling the earlier "slower" section, dyads are formed from $\mathrm{O}^{0}$ (marked in line 1 of Ex. 1: dyads 1-8 in forward order, stems up; a different grouping 1-8 in reverse order $\left(R^{0}\right)$, stems down) to accompany a free declamation on the remaining notes.

Pp. 14-15. Paralleling the opening passages, the men sing $\mathrm{RI}^{0}$ followed by $\mathrm{I}^{0}$ (turning point at the second syllable of "crown-est") against a background of solo women's voices based on freely-articulated segments of the g-minor triad.

Pp. 15-17. Sopranos and altos sing "London New" to the first verse as paraphrased in the BayPsalm Book. They employ a standard early rhythmic form of Common Metre with elongations of the first and last syllables of each phrase. Tenors and basses "harmonize" freely; the three-part sonority is based on the 


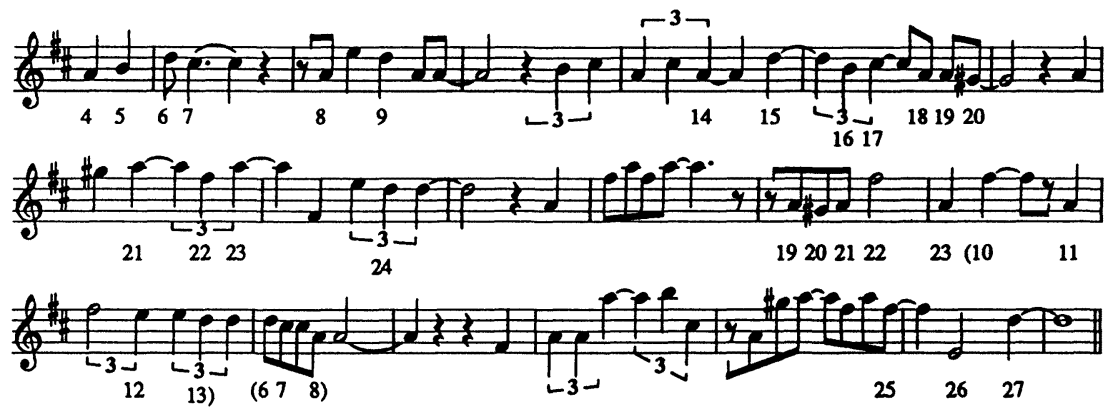

Example 2
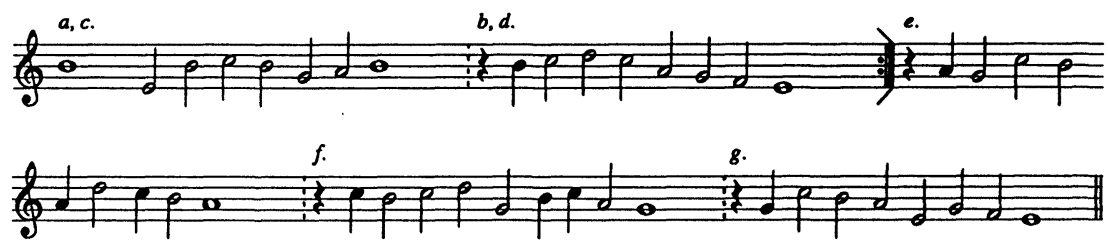

Example 3

notes and intervals prevalent in the melody itself. Solo soprano voices sing a free fourth line in quicker prose rhythm, to the verses of the Psalm. This was, I think, composed spontaneously with the idea of making a high-pitched "laughing" counterpoint to the plain hymn-tune. But the notes do refer at times to the given melody, straightforwardly at first and then more floridly, perhaps in the same way the cantus firmus is treated in some of the Palestrina paraphrase masses spinning out the original line with repetitions, passing notes, and other devices. The possible references (I do not vouch for their being all the result of conscious planning) to the 28 notes of "London New" are indicated in Ex. 2.

No.2 (Psalm CXXX). The traditional chorale is shown as Ex. 3. The correspondence of the starting "deep" descent of a perfect fifth to the word "tiefer" has often been noted.

"Prelude," pp. 3-4. The first half of the first verse of the psalm-text is spoken in English by overlapping voices, the basses entering first and the sopranos last. Each group breaks up the line in a different way. In a note to the performers, I request that the words here be "projected in natural speech rhythm, moderately 
loud, and with feeling." While the women finish this, the men sing the same text in unison in Latin, slowly and emphatically, but in broken fashion, to the notes of the first phrase of the chorale.

Pp. 4-10. The main body of the setting is structured somewhat in the manner of a chorale-prelude by Buxtehude. The eight verses of the English psalm text alternate with the seven lines of the chorale, sung in German (the text being a paraphrase of verses $1-3$ of the original). The density varies as follows:

number of
voices

$\begin{array}{llll}\text { Psalm v.1 } & 2 & \text { Chorale } 1.4 & 1 \\ \text { Chorale } 1.1 & 1 & \text { Psalm v.5 } & 2 \\ \text { Psalm v.2 } & 2 & \text { Chorale } 1.5 & 3 \\ \text { Chorale } 1.2 & 1 & \text { Psalm v.6 } & 4 \\ \text { Psalm v.3 } & 1 & \text { Chorale } 1.6 & 2 \\ \text { Chorale } 1.3 & 2 & \text { Psalm v.7 } & 2 \\ \text { Psalm v.4 } & 3 & \text { Chorale } 1.7 & 1 \\ & & \text { Psalm v.8 } & 1\end{array}$

number of voices (A, 11 notes, and B, 7 notes: see Ex. 4), which are treated serially. The transpositions are restricted to those a fifth above $(=7)$ and a fifth below $(=5)$, and only $\mathrm{O}$ and $\mathrm{R}$ positions are used; therefore the only "new" pitches added to the E-Phrygian scale of the original chorale are B-flat and F-sharp. Ex. 4 shows the serial orders.

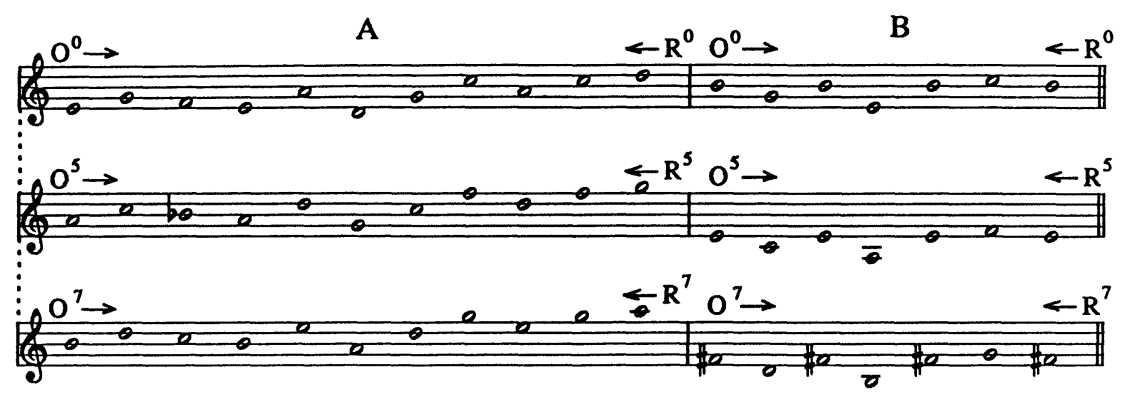

\section{Example 4}


The chorale melody is carried by these voices:

$\begin{array}{llll}\text { line } 1 & \text { alto } & \text { line } 5 & \text { tenor } \\ \text { line } 2 & \text { tenor } & \text { line } 6 & \text { soprano } \\ \text { line } 3(=1) & \text { bass } & \text { line } 7 & \text { bass } \\ \text { line } 4(=2) & \text { soprano } & & \end{array}$

Counterpoints in lines 3,5 , and 6 are free, though based on the scale and intervalcharacter of the chorale.

"Postlude," p. 11. The reverse procedure to the "prelude" is applied. The spoken text in English again consists of the first half of verse 1 of the Psalm, but here the order of voices is high to low - i.e., the sopranos enter first and the basses last. The sung notes are taken from the seventh (last) line of the chorale tune, and are given this time to the women's voices in unison. The final sound is of two solo spoken voices in the deep bass range overlapping softly on the second half of the first verse, "Lord, hear my prayer."

No.3 (Psalm I). The Genevan psalm-tune (or chorale), Ex. 5, lines 1-2, is one I vividly remember from an old Haydn Society recording. ${ }^{4}$ The choir began it in plain unison - or rather, an octave doubling of male and female voices - just as one imagines a group of the original users singing it, in a social circle or in school or around the domestic hearth, or (less likely) in a service of worship. The choir then continued with a polyphonic setting, the first of Goudimel's eight psalmmotets of 1551. I recalled also the more homophonic setting of Louis Bourgeois

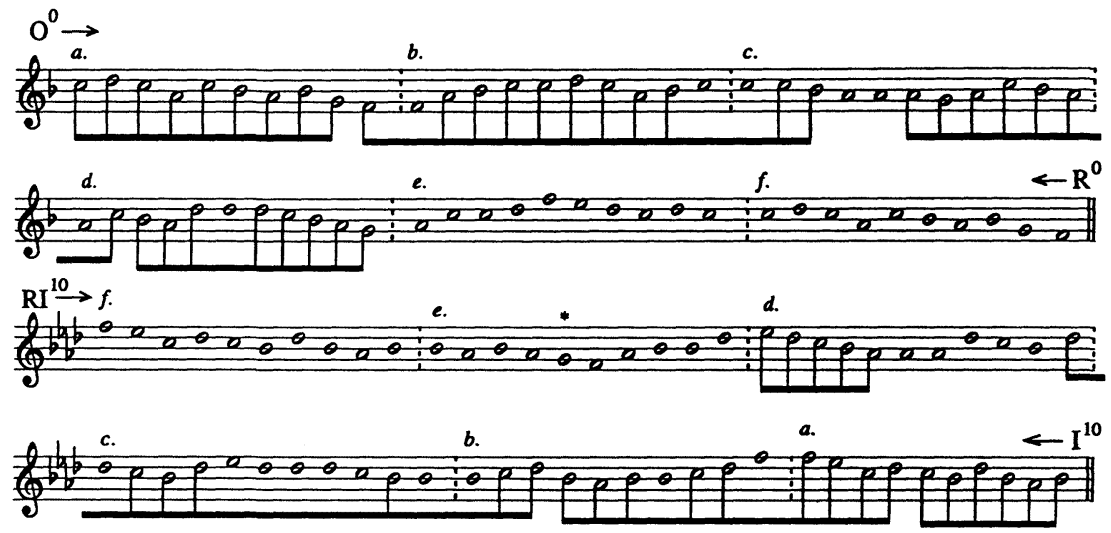

\section{Example 5}

${ }^{4}$ Haydn Society AS 41, 1954. 
in Apel's Historical Anthology ${ }^{5}$, which I used to teach to my history of music classes.

Pp. 3-6. My setting therefore starts in octaves, using the original French verseparaphrase, probably by Clément Marot, equivalent to the first two verses of the Psalm. In this rather plain introduction each phrase is echoed by the tenors singing the equivalent $\mathrm{RI}^{10}$ - i.e., the $\mathrm{RI}$ transposed so as to relate to the same "tonic" as $\mathrm{O}^{0}$; see Ex. 5, lines 3 and 4. (One pitch is altered, at the asterisk, $\mathrm{G}$ instead of the stricter G-flat. I discovered this little mistake only while preparing these notes, and felt reluctant to correct it. Purist choir directors are welcome to change the tenors' G, an eighth note on "et," third system of p. 5, to G-flat.) As in No. 1, the major diatonicism of the melody becomes minor when the I and RI forms are used; so again a kind of bimodality is created, as if the F major melody is being bounced back, phrase by phrase, in B-flat Dorian. The tenor "echoes" are in quicker and less uniform note-values; the resulting nervousness of motion, added to the tension of bimodal clashes, may reflect the text's contrast between righteousness and ungodliness.

Pp. 6 (bottom), 10 (top) and 13 (bottom). A refrain is formed from the opening words of this Psalm, set to a progression of four chords (see Ex. 6). This is revoiced and expanded in its two later appearances. The rather "juicy" chromaticism of the final cadence may smack of Messiaen, if not Gershwin; apart from its appropriateness to a bible-lesson or sermonette such as this Psalm, this characteristic may be implied in the free chromaticism of the main body of the piece.

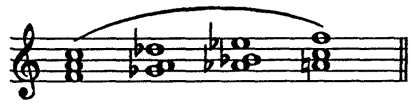

Example 6

Main body (pp. 7-9 and 10 (bottom) - 13 (top): For verses 1-4, the men sing in quick uneven prose rhythm. The pitches of the thirty-three accented syllables in their lines are taken from the first four phrases of the Genevan psalm melody (omitting some repeated notes, as indicated in Ex. 5 by stems) and these are doubled an octave higher by the mezzo-sopranos. The unaccented syllables are given to nearby pitches (akin to neighbour or passing notes) but these are sharpened or flattened arbitrarily with a view to inflecting the original diatonic F major with chromatics. Between these phrases the sopranos and altos sing twopart canonic "echoes." The soprano line is formed from the retrograde of the chorale line (i.e., beginning at the end of phrase 4 of the chorale melody and

${ }^{5}$ Historical Anthology of Music, vol. 1, ed. W. Apel and A.T. Davison. Cambridge: Harvard University Press, 1946. See example 132. 
proceeding backwards to the start). The canon is at the fourth below in echoes 1 and 3 , and at the fifth below in echoes 2 and 4 .

For verses 5-6, a similar plan is used. The women now sing the principal phrases, using the inversion $\left(\mathrm{I}^{0}\right.$, reading in retrograde in Ex. 5, the pitches indicated by stems) of lines 1,2, and 4 of the chorale melody, emphasized at the lower octave by the baritones, joined together by blurring chromatic pitches on unaccented syllables. The echoes, sung by the tenors and basses, employ $\mathrm{RI}^{10}$, and the canons are at the fourth below in echoes 1 and 3, and the fifth below in echo 2 .

Verse 7 is set to line 5 of the chorale in $\mathrm{O}^{0}$ and $\mathrm{RI}^{10}$ forms. The texture - full choir in unison rhythm answered by tenors - recalls the introductory section, although the prose declamation, English text, and doubling in fifths are features of the main body. Thus this verse plays both an affirming role, in its employment of the climactic phrase of the given melody, and a recapitulatory one, in its implied recollection of the start of the piece: these features perhaps serve to underline the "moral" of the psalm text.

No. 4 (Psalm LXXX). The source-tune, given in its original key and metre in Ex. 7, was named for "the Foundry," East-London headquarters of John Wesley and his followers. It may have been composed by Johann Friedrich Lampe, unofficial musical adviser for the movement's early publications; no composer is credited. "Foundery" represents a mid-18th-century type of slow, melismatic, triple-metre melody quite distinct from the plainer English and Scottish style of earlier days. Its structure is binary with repeats - a, a, b, b. The "a" and " $b$ " components are often separately dealt with in the setting. No. 4 contrasts with the other movements in the cycle in being slower and longer and also in being more essentially variational. The coiling or "turning" quality in the given tune was found especially appropriate to the text.

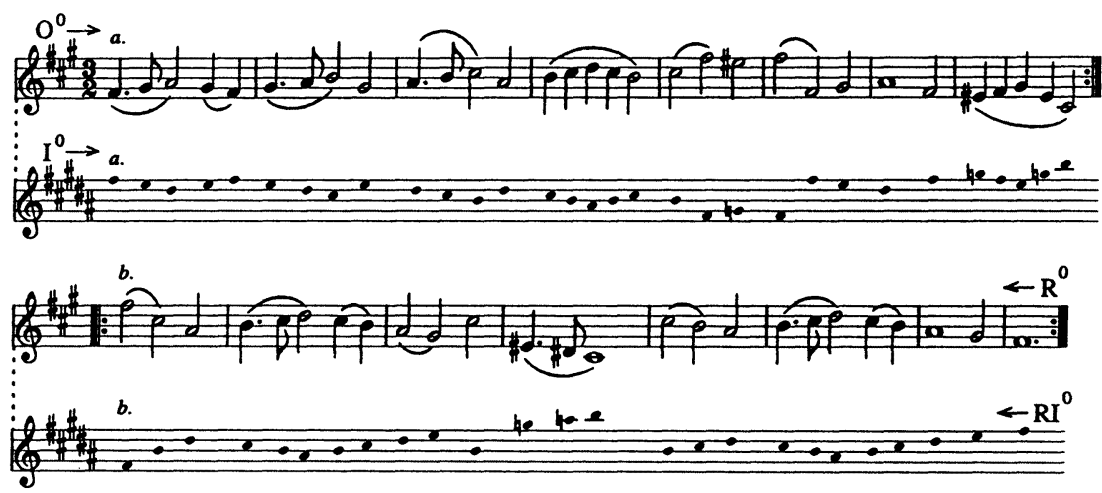

Example 7 
Pp. 3-5. Sopranos and altos sing a duet on $\mathrm{O}^{0}$ (both halves, repeated), while tenors and basses sing a dialogue of derived interrupting phrases.

Pp. 5 (bottom) -6 . The textual refrain: tenors and basses sing a duet based on $\mathrm{I}^{3}$ (both halves, but without repeats).

Più mosso, pp. 6-8. The choir sections share a single line. This is $\mathrm{R}^{10}$ of $\mathrm{b}, \mathrm{a}$, and a again, distributed among the four voice parts with sevenths and ninths replacing many of the seconds, and with constant vocal glissandi. The glissandi are intended to be slow, with a "wailing" expression.

Pp. 8-9. The refrain this time is a duet for altos and tenors, based on $\mathrm{RI}^{10}$ (a, $\mathrm{b}-$ no repeats).

Con moto,pp. 9-10. A double duet (sopranos and altos against tenors and basses) based on parts of $\mathrm{I}^{0}$ (a repeated, $\mathrm{b}$ omitted) is balanced by a second double duet (altos and tenors against sopranos and basses) based on parts of $\mathrm{I}^{7}$ (again a repeated, $b$ omitted).

P. 11. The sudden loud minor triad in root position may have been suggested (unconsciously) by the death of Mimi in La Bohème. The harmonic progressions are formed from simultaneous presentations of $\mathrm{O}^{10}$ and $\mathrm{R}^{10}$ (b only; the derivation is shown in Ex. 8). This is followed by a similar treatment based on $\mathrm{R}^{5}$ and $\mathrm{O}^{5}$ of $\mathrm{b}$.

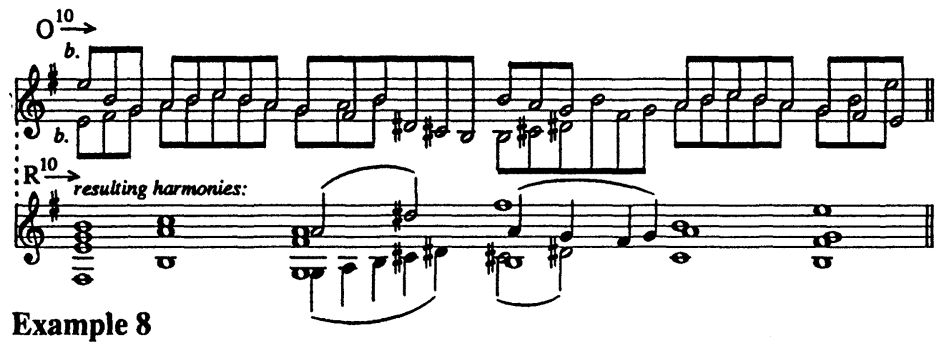

Pp. 11(last note)-17. The original tune in $\mathrm{f}$-sharp minor, harmonized following 18th-century practice, is interrupted by bitonal phrases in faster tempo, based on imitations of fragments of the set. The sources are:

$\begin{array}{cccc}\text { interrupting phrase } & 1 & \mathrm{~b}, \mathrm{R}^{7} \text { and } \mathrm{R}^{0} \\ \text { “ } & \text { “ } & 2 & (\mathrm{~b}), \mathrm{a}, \mathrm{R}^{7} \text { and } \mathrm{R}^{0} \\ \text { “ } & \text { “ } & 3 & \mathrm{a}, \mathrm{R}^{7} ; \text { other fragmentary references } \\ \text { “ } & \text { “ } & 4 & \mathrm{~b}, \mathrm{O}^{2} \text { and } \mathrm{O}^{7} \\ \text { “ } & \text { “ } & 5 & \text { fragmentary references } \\ \text { “ } & \text { “ } & 6 & \text { “ } ~\end{array}$


Pp. 17 (bottom) - 19. As in the opening section of the piece, a duet, this time of tenors and basses based on $\mathrm{I}^{3}(\mathrm{a}, \mathrm{a}, \mathrm{b}, \mathrm{b})$, is interrupted periodically by a dialogue, this time of sopranos and altos but following the same sequence as in the opening section and affording thereby a bimodal (major/minor) quality.

Pp. 19 (bottom) - 20. For the final refrain sopranos and altos sing a duet based on $\mathrm{O}^{0}(\mathrm{a}, \mathrm{b})$ to which tenors and basses add a pedal note.

No. 5 (Psalm CXLVIII). Robert Lowry's original and familiar tune appears in full as Ex. 9. An influence on this setting was a British television production shown in 1985 in which a rock band performed Psalm 150 to a visual interpretation by puppets. Though I hated the way it was executed, I liked the idea that a few chords hypnotically repeated in fast rhythm could convey the exuberance of that Psalm's cymbal-crashing praises. Using an equally exuberant text, No. 5 concentrates on the three basic chords (tonic, dominant, subdominant) of the original. The chords appear almost always in Lowry's spacing and with his "nonharmonic" embellishments, including the B-naturals and E-naturals of bars 9,11 , and 13. As it were, segments of the whole tune are juxtaposed in collage, and suited to the natural word-rhythms of the text, in animated tempo. There is no systematic paraphrasing, and no overt quotation from "Beautiful River," although the opening of the setting follows its opening progression. There is some text repetition, and the opening phrases of the two stanzas are recapitulated at the end. As in folk and rock music I was occasionally hearing in 1984 and ' 85 , the setting ends on the "subdominant," as if on the syllable "A-" of an incomplete plagal "A-men" from the 19th century.

No. 6 (Psalms CXXII and LXXXVII). The five sections follow an arrangement represented by the letters $a, b, c, b, a$.

Pp. 3-6. Ex. 10 shows Stephen Humbert's original melody in larger notes with his original accompanying voices in smaller notes, and, below this, a slight reduction of this three-part harmony to its essential progressions. The five phrases of "Remembrance" appear in the women's voices at the start, as follows:

$\begin{array}{clll}\text { phrase } & \mathrm{a} & \text { bars } & 1-7 \\ \text { “ } & \mathrm{b} & \text { “ } & 8-18 \\ \text { “ } & \mathrm{c} & \text { “ } & 19-25 \\ \text { “ } & \mathrm{d} & \text { “ } & 26-32 \\ \text { “ } & \mathrm{e} & \text { “ } & 33-40\end{array}$

A free quasi-heterophonic two-part counterpoint is added by the men's voices. Here pitches are chosen to neutralize the tonal feelings of the original, without deviating from the basic scale of $\mathrm{C}$ major. 

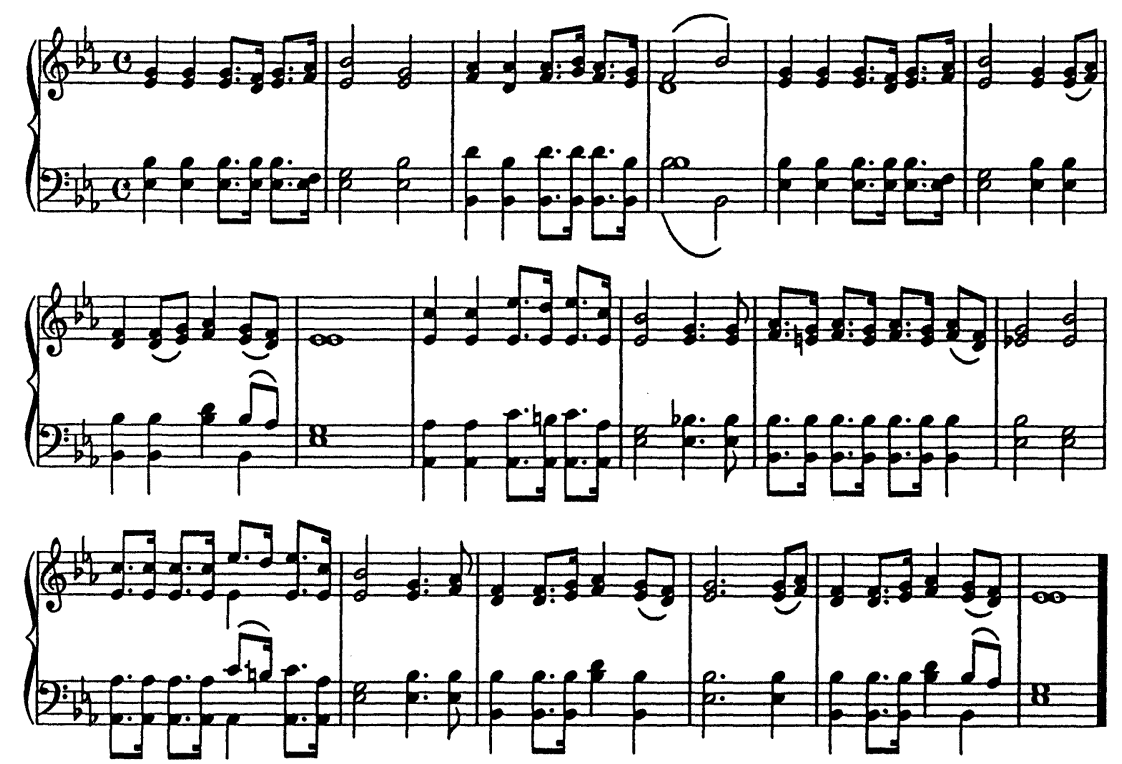

Example 9
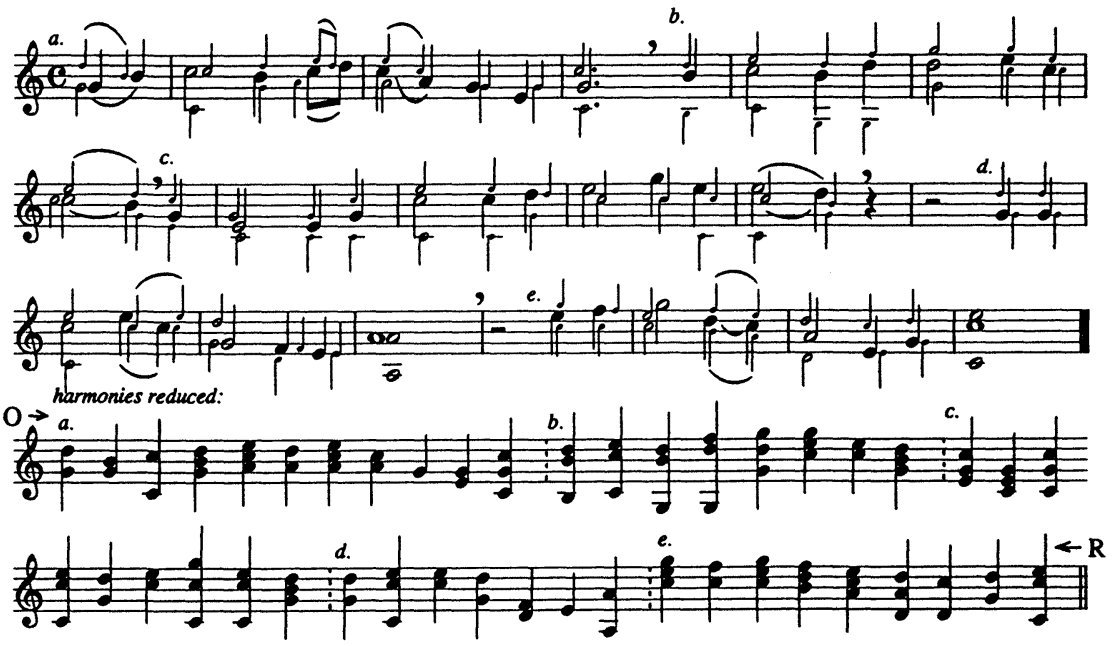

Example 10 
Pp. 6-8. The sub-choir sings Humbert's original melody, more conventionally harmonized, in A-flat major. The melody is in the bass part. Prose interjections by the full choir employ a chant-like monotone with some dissonant neighbournotes for emphasis.

P.9. All voices share the $R^{5}$ version of the original sequence of progressions (see " $R$ " in the last part of Ex. 10).

Pp. 10-13 (corresponding to 6-8). The sub-choir sings the original tune in B-flat major, with the melody in the treble and other parts based on the harmonization heard before in A-flat and the prose interjections more or less as before. A link is set to a key phrase, "O pray for the peace of Jerusalem," sung piano by solo voices without harmonization.

Pp. 13 (middle) - 15 (corresponding to the opening). For the first four phrases, the original three-part progressions are found in the men's voices and the added two-part counterpoint in the women's voices. But in the fifth phrase (a textual repetition) the distribution is identical to that found in the opening section of the piece.

The title Harp of David was chosen in imitation of those early-nineteenthcentury tunebooks (Lute of Zion, Sacred Harp) that had such a strong formative influence on North American musical culture. On my original manuscript titlepage I photocopied an engraved figure of the robed and crowned harpist from the Psalter published by Andro (= Andrew) Hart in Edinburgh in 1615. I realize that the cycle, written to no commission, places demands on both performers and auditors; if my concept needs defending, I would say I look on it as a celebration of the richness of expression and variety of musical shapes found in vernacular music. (If hymn tunes and chorales are not "people's music," what is? I keep telling colleagues whose eyes glaze over when I become enthusiastic on the subject that this, rather than any minutiae of the texts, is their primary attraction for me.) My hope is, of course, that the mix of old vernacular materials with treatments and procedures which may be considered new will strike echoes with others. 